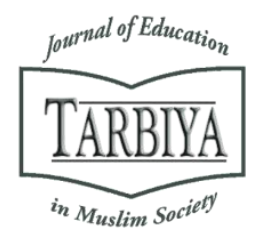

Available online at TARBIYA: Journal of Education in Muslim Society Website:

http://journal.uinjkt.ac.id/index.php/tarbiya

TARBIYA: Journal of Education in Muslim Society, 7(2), 2020, 226-240

\title{
SUCCESSFUL ACCREDITATION TECHNIQUES
}

Shirley Baker*, Sherry Camden-Anders

Alliant International University, USA

E-mail: sbaker@alliant.edu

Received: $19^{\text {th }}$ September 2020; Revised: $27^{\text {th }}$ November 2020; Accepted: $28^{\text {th }}$ Desember 2020

Abstract

The challenges of accreditation reviews create a sense of stress across academic institutions that can be significantly reduced when strategies are implemented and maintained. Understanding the purpose, value, and benefits of the accreditation process is critical. Two techniques that lead to accreditation success include ongoing program meetings resulting in assigned tasks that address government or commission evaluation standards, and the use of a program matrix. The article includes meeting strategies and a universally adaptable matrix design. Moving from stress to success is possible when the techniques are linked to all standards and subsections, and each task successfully meets accreditation requirements.

Keywords: accreditation techniques; successful accreditation; Meeting Technique; program matrix

\section{Abstrak}

Tantangan akreditasi menciptakan rasa stres di seluruh institusi akademik, hal ini dapat dikurangi, secara signifikan ketika strategi diterapkan dan dipertahankan. Memahami tujuan, nilai, dan manfaat dari proses akreditasi sangatlah penting. Dua teknik yang mengarah pada keberhasilan akreditasi, termasuk program rapat yang sedang berjalan sehingga menghasilkan tugas-tugas saat membahas standar evaluasi pemerintah atau komisi, dan penggunaan matriks program. Artikel ini mencakup strategi rapat dan desain matriks yang dapat disesuaikan secara universal. Beralih dari rasa stres akan keberhasilan akreditasi, hal ini memungkinkan jika teknik ini dikaitkan dengan semua standar dan subbagian, serta setiap tugas yang berhasil memenuhi persyaratan akreditasi.

Kata kunci: teknik akreditasi; kesuksesan akreditasi: teknik rapat; program matrix

How to Cite: Baker, S., Camden-Anders, S. (2020). Successful Accreditation Techniques. TARBIYA: Journal of Education in Muslim Society, 7(2), 226-240. doi:10.15408/tjems.v7i2. 20592.

Permalink/DOI: http://dx.doi.org/10.15408/tjems.v7i2. 20592 


\section{Introduction}

This article presents a literature review discussing the purpose, value, and benefits of the accreditation process and focuses on two techniques that led to the successful reviews of a Master's degree program for Teaching English to Speakers of Other Languages (TESOL). The techniques facilitated meeting the requirements for accreditation and connected the standards to the task assignments of the TESOL team. Well planned and collaborative meetings and a program matrix provided evidence of student learning outcomes and professional competencies.

The university, located in Southern California, provides undergraduate, Master's, and doctorate degrees. The TESOL Master's program accreditation reviews were passed in 2009, 2014, and 2019. The TESOL directors and faculty collaborated to hone key techniques that were the foundation for successfully passing all accreditation standards. Even though the accreditation teams requested wording clarification or additional documentation, they noted the high quality of organization, depth of information, wealth of documentation, and accurate representation of all commentary and student learning achievements.

The literature review focus is centered on higher education. The TESOL meeting techniques and matrix techniques may be applied as models applicable across fields and should not be considered as valuable only to a single discipline. For example, the Program Matrix will have a Master's in Teaching English to Speakers of Other Languages format, but the matrix design is adaptable to most disciplines and degree levels (undergraduate, Master's or doctorate).

\section{Accreditation Relevance}

Understanding the purpose, value, and benefits of accreditation is fundamental to success when planning to meet the commission's standards. According to Choiriyah, Kumaidi, and Kartowagiran (2018):

Practices in quality assurance relate to assessment and benchmarking....[a] university's quality is therefore determined by its output, such as whether or not it uses its resources efficiently to produce highly skilled, employable graduates. Quality is defined by the customer, and management is responsible for achieving that quality. (p.180)

Accreditation reviews are a global phenomenon for higher education institutions (Mc Allister \& Nagarajan, 2015; Choiriyah, Kumaidi, \& Kartowagiran, 2018; Rosyidah, Matin, \& Rosyidi, 2020). Assessments include degree programs and the academic institution as a whole because the standards address every entity of higher education institutions (Rosyidah, Matin, \& Rosyidi, 2020). Some disciplines are reviewed by field-specific, comprehensive standards and are part of specialized accreditation agencies such as the library and information sciences, health care, and business degrees (Gibbons \& White, 2019). Mc Allister and Nagarajan (2015) explained that in Australia, accreditation of allied health courses is an essential requirement that ensures educational effectiveness and quality assurance that is maintained through annual program reviews.

\section{Purpose}

Using peers and experts external to an institution significantly diminishes an organization's internally directed agendas and biases when conducting a self-study. The purpose of accreditation commissions is to provide systematic processing, assure quality, and verify program academic integrity (Prince, 2012). The seven United States regional accreditation commissions are nongovernment entities. The government exerts control over educational 
institutions through the success or failure of the periodic accreditation reviews; federal and state funding may be withheld or reduced based on the accreditation results (Prince, 2012). Casazza (2018) stated that "...accreditation is based on standards designed to hold institutions accountable to an external agency for obtaining funding from the federal government" (p. 30).

Rosyidah, Matin, and Rosyidi (2020) stated that "Getting accreditation with the best result is the expectation of every university and international accreditation is a promotion force..." (p. 357). Notably, some nations have governments setting the standards, including directing the curriculum and designation of possible degree programs.

Accreditation commissions, such as the Western Senior College and University Commission (WSCUC), have clearly defined standards that are subdivided into sections that allow each academic institution to understand and then produce the explanations, documents, and related resources to substantiate their responses to each standard element. WSCUC was the accrediting body that reviewed the TESOL Master's program.

The WSCUC has four standards with multiple subdivisions that further clarify all elements that must be met:

$\begin{array}{llrr}\text { Standard One: } & \text { Defining } & \text { Institutional } \\ \text { Purposes and } & \text { Ensuring } & \text { Educational } \\ \text { Objectives. } & & & \end{array}$

Standard Two: Achieving Educational Objectives through Core Functions.

Standard Three: Developing and Applying Resources and Organizational Structures to Ensure Quality and sustainability.

Standard Four: Creating an Organization Committed to Quality Assurance, Institutional Learning, and Improvement.
The TESOL Master's Program was under WSUC accreditation reviews. While all the standards were part of the program review process, the WSCUC Standards Two and Four provided the most direct criteria for passing the TESOL reviews:

Standard Two: Achieving Educational Objectives through Core Functions.

The institution achieves its purposes and attains its educational objectives at the institutional and program level through the core functions of teaching and learning, scholarship and creative activity, and support for student learning and success. The institution demonstrates that these core functions are performed effectively by evaluating valid and reliable evidence of learning and by supporting the success of every student.

Standard Four: Creating an Organization Committed to Quality Assurance, Institutional Learning, and Improvement.

The WSCUC Standard Two was relevant to the two techniques used in the accreditation of the TESOL program. The emphasis here is not the interpretation and full responses to the standards and subsections. The article discussion explains how the two techniques provided evidence to meet Standard Two. The WSCUC (2013) commissions' purpose is to set the achievement benchmarks for academic institutions regarding academic rigor, high standards of operation, elevated faculty expertise and experience, appropriate staff assistance and knowledge, and student success in educational endeavors and career preparation.

Different commissions address the same review quality expectations but use different standard styles (NWCCU, 2020). The Northwest Commission on Colleges and Universities (NWCCU) (2020) identified two 
standards with numerous subsections. The NWCCU (2020) standards are:

Standard One: Student Success, and Institutional Mission and Effectiveness.

The institution articulates its commitment to student success, primarily measured through student learning and achievement, for all students, with a focus on equity and closure of achievement gaps, and establishes a mission statement, acceptable thresholds, and benchmarks for effectiveness with meaningful indicators. The institution's programs are consistent with its mission and culminate in identified student outcomes leading to degrees, certificates, credentials, employment, or transfer to other higher education institutions or programs. Programs are systematically assessed using meaningful indicators to assure currency, improve teaching and learning strategies, and achieve stated student learning outcomes for all students, including underrepresented students and firstgeneration college students.

Standard Two: Governance, Resources, and Capacity.

The institution articulates its commitment to a structure of governance that is inclusive in its planning and decision-making. Through its planning, operational activities, and allocation of resources, the institution demonstrates a commitment to student learning and achievement in an environment respectful of meaningful discourse. (p. 1-3)

The various standards for NWCCU accreditation were provided to offer resources for academic institutions to refresh or enhance their preparations for passing current or future accreditation reviews.

Accreditation is the process for evaluating the changes needed to improve all aspects of an institution, especially the quality of teaching and learning, student application of knowledge and applicability toward professional expertise, and research-based decisions (Oraison, Konjarski, \& Howe, 2019). Accreditation provides the time, focus, and resources to stimulate motivational teaching, in-depth research, and greater learning comprehension.

Value

Standards set the benchmarks for programs to address their strengths and weaknesses. An additional value is a rigorous self-study that allows institutions to enhance programs and improve their academic standing. Addressing the National Association for Developmental Education (NADE) Accreditation process, Ferguson and Ludman (2018) noted that "Accreditation is the vehicle to validate the quality of what you do.... Accreditation promotes the value of your program with internal and external stakeholders. Accreditation gives you a voice to speak with authority about the student success and program design” (p. 10).

\section{Benefits}

Western Washington University (2006) stated that "When faculty members are directly involved in the development, implementation, and analysis of assessment activities, a number of specific benefits result" (p. 24). Accreditation assessments and data tracking benefits include specific insights into student development, the effects of curriculum, teaching methods, and instructional materials, and provides evidence of students learning needs and their accomplishments (WWU, 2006).

The TESOL team members met regularly and the benefits were evident beyond the fully developed syllabi and rubrics, as transparency, cohesiveness, and better solutions to problems became the norm. It was a meaningful part of the process for the directors, faculty, staff, and 
administrators to participate in the assessment and accreditation process.

\section{Commission Process}

Numerous US and international commissions or government agencies have summarized guidelines and checklists for meeting topics and from the standards that encompass the checklists, meeting facilitators can organize agendas, work with the team to assign tasks, and develop completion timelines. All team efforts should focus on preparing the evidence that confirms all standards are met.

The National Association for Developmental Education (NADE) provided conceptualization strategies to meet standards that closely resembled the TESOL team meetings. Because the team met regularly, most of the steps were already addressed. NADE has an accreditation packet with guidelines and a checklist that would benefit institutions preparing for years to come with accreditation visits. "NADE Accreditation requirements promote a culture of evidence and continuous improvement for the Developmental/Transitional programs dedicated to student success in colleges and universities" (NADE, 2018, p. NA). Universities could select team members and design a timeline for standard task completions using the NADE checklist.

Ferguson and Ludman (2018) introduced the following NADE checklist and considerations:

...the accreditation process is very linear: 1 ) complete the application narrative, 2) complete the self-study, 3) collect and analyze two years of base-line data, 4) create and implement an action plan, 5) collect and analyze two years of comparative data, 6) collect and analyze data required on the minimum data templates (both baseline and comparative), and 7) put it all together and turn in the application.

However, in reality, the process is rarely that straightforward. Applicants may decide to start with the self-study and then work on tasks such as mission, goals, and theory simultaneously. Sometimes applicants already have data that can fit the requirements of the baseline data for the application so that data becomes the starting point. Wherever applicants start, the process is likely to be quite recursive, but it is helpful to keep the "straight line" laid out in order to see where all the pieces need to fit in the end. The application packet consists of several sections. (p. 9)

As authored by Corpus (n.d.) the Accrediting Agencies of Chartered Colleges and Universities in the Philippines (ACCUP) organized a concise flow of accreditation procedures and a general criteria list that identifies the areas that are normally assessed. The Council for Higher Education Accreditation-International Quality Group (CHEA-IQG) based in Washington, D. C., U.S.A. is affiliated and works with ACCUP along with other Asian accreditation agencies (Corpus, n.d.). The criteria list is beneficial for review and for those not acquainted with the breadth and depth of an accreditation process. Corpus (n.d.) identified the process and stages of accreditation:

- Application - an educational institution files its application to undergo accreditation with AACCUP.

- Institutional Self-survey - upon approval of the application, the applicant institution will be required to make an internal assessment by its internal accreditors to determine the program's readiness for external review. 
- Preliminary Survey Visit - the evaluation of the program for the first time by external accreditors. Passing the assessment entitles the program to be awarded a Candidate status valid for two (2) years.

- 1st (Formal) Survey Visit - the evaluation of the program which has attained Candidate status, and if it has attained a higher level of quality, is awarded a Level I Accredited status, good for three (3) years.

- 2nd Survey Visit - involves the evaluation of an accredited program, and if it has passed the standards set at a higher level of quality than the immediately preceding survey visit, may qualify the program to an award of Level II Re-accredited status, good for five (5) years.

- 3rd Survey Visit - the accreditation stage conducted after a program has enjoyed a Level II Re-accredited status for five (5) years. Passing a higher-level standard of quality entitles the program to apply for Level III. The program is then evaluated and must excel in four (4) areas, namely: 1) instruction and 2) extension, which are mandatory; and two (2) more areas to be chosen from among research, performance in licensure examination, faculty development, and linkages.

- 4th Survey Visit - is a higher level which if hurdled, may entitle the institution to an institutional accreditation status. (p. 1)

The ACCUP visits are indicative of other commissions' timelines for initial and return visits. The visits can be spaced from one, three, to five years depending on the accreditation success of individual programs and the overall institution assessment. The processes and documentation resources were the same for both the Master's and Doctorate degrees, just adjusted for each program level.

\section{Meeting Technique}

A meeting timeline was developed, and carefully planned agendas were selected. The three directors and the technology expert met regularly, adding appropriate professors, students, or staff to share in the discussions. The benefits of respectfully listening to each person's ideas, expertise, experience, and suggestions created transparency and shared responsibility for achieving the standards and providing documentation. Involving those relevant to different aspects of the review produced individual responsibility and shared success when the standards were met (Ilays, 20). The TESOL team felt bonded and mutually rewarded when the process was finished. A well-developed timeline "...reduces stress and encourages the depth of reflection necessary for such a farreaching process" (Bahr, 2018). Everyone felt rewarded when the accreditation team expressed their appreciation for the obvious hard work, attention to detail, and noteworthy results of student learning outcomes motivated by dedicated teaching and program administration.

The TESOL Master's program had a small faculty with a TESOL Director and the Systemwide TESOL Director, university technology support, staff, and course professors that included adjuncts. Regular meetings were arranged and task progress reports were discussed, if needed, suggestions for assistance were offered.

\section{Meeting Focus}

The on-going TESOL meetings addressed the criteria similar to the Higher Learning Commission's (2020) Teaching and Learning: Evaluation and Improvement criterion. "The 
institution demonstrates responsibility for the quality of its educational programs, learning environments, and support services, and it evaluates their effectiveness for student learning through processes designed to promote continuous improvement" ( $p . N A)$.

For the TESOL team, the ongoing meetings had focused strategies that included the WSCUC criteria and other checklists to achieve a welldesigned, expertly taught, and student accomplished program. Rosyidah, Matin, and Rosyidi (2020) clarified that

... the meaning of strategy in the context of higher education institutions is the efforts of higher education institutions in the form of plans, actions, and tactics to achieve goals.

The plan can be a statement of vision, goals, and expectations to achieve. The pattern of action can be in the form of programs and activities carried out in an effort to achieve goals. The tactic is the effort made to achieve goals and position institutions with certain characteristics. (p. 352)

A list of the various commissions' criteria correlated with the TESOL meeting strategies for aligning the tasks assigned to satisfy standard requirements (WSCUC; NWCCU, 2020; NADE, 2018; HLC 202; and Corpus, ACCUP, 2016:

\section{Criteria}

- Vision, Mission, Goals, and Objectives: Evidence provided on each course syllabi (Previously created and determined in the initial development of the program).

- Faculty and Staff: All core faculty have doctorate degrees Adjunct faculty have Master's or doctorate degrees. For each course, instructors receive student evaluations; Staff members are trained to support TESOL graduate students as they progress through the program.

- Curriculum, Instruction, and Professional Development: On-going strategy meetings keep courses aligned with rigorous content and professional development opportunities. All course assignments have a rubric or guidelines that lead students to demonstrate professional competencies. Continuous discussions and task assignments are focused on maintaining and meeting accreditation teaching and learning standards.

- Research: Faculty and students perform research and publication opportunities.

- Community Involvement: TESOL courses include assigned student teaching at community centers.

- Library: Updated TESOL references are requested on a semester basis. The library services fall under the institutional accreditation process.

- Physical Facilities: Addressed under the institutional accreditation process.

- Technology: Staffing, computers and associated requirements, updated training, and maintenance are related to institutional accreditation.

- Administration and Stakeholders: The TESOL Systemwide Director and Program Directors receive yearly evaluations. Other administration and governing board issues fall under the purview of institutional accreditation.

\section{Task Assignments}

The TESOL team assignments were related to a specific standard or substandard until every issue was resolved. Tasks included one course being assembled, in hard copy and on a flash drive, from the syllabus through every week's agenda, teaching PowerPoints and notes, to 
include class materials, rubrics for each assignment, resource materials, discussion topics, notes on student input, and finally evidence of student products with grades and accompanying teacher comments.

Other courses had portions provided in hard copy and on flash drives that had unique materials or teaching content. For example, the Research and Design course had excellent instructions for creating in-depth literature reviews; therefore, the instructions and graded student products were assembled for the accreditation team (grades and teacher commentary included).

Another course had innovative guidelines and expectations for the ethnographic study where students were to visit with parents of students from different cultures, religions, and ethnicities. The graduate students explained that they had a course assignment to learn from the diverse families themselves how to better support and teach their children in an English language classroom.

One course student learning objective was to have students step beyond what they believed they knew about another culture or religion and actually learn from those within the culture or faith expression. Students arranged a time to meet with families and gain insights about the unique perceptions specific to their diverse cultural, ethnic, or religious backgrounds. Students then wrote a comprehensive paper sharing the respectful questions they asked to gain insights and the responses parents shared. Students discussed the broadening of their own knowledge regarding the differences they observed and learned from the families. The graduate students explained how they would apply the insights to their teaching and support for students. The assignment was a course highlight. The class materials, guidelines, and the students' ethnographic papers were evidence that respect for diversity and strategies for inclusion are essential for best practices teaching and student learning. The student learning outcomes were exceptionally powerful as respect for diversity was evident throughout their final products and presentations.

\section{TESOL Professional Development}

Each course had examples of motivational teaching, and student engagement in learning.

The meetings also had instructors document how their classes would provide opportunities for professional experience (Oraison, Konjarski, \& Howe, 2019). Evidence included student PowerPoint presentations and submitted papers for TESOL conferences. Teaching English reading, writing, listening and speaking classes, for a set period, were also demonstrations of actual teaching development as they created their own lesson plans under the guidance of the course instructors. The students submitted reports for each class taught and received feedback from their instructors.

Lucas, Fleming, and Bhosale (2018) completed a case study research project that focused on the importance of work-integrated learning (WIL) that further enhanced the connection between higher education and government, professions, business, industry, and numerous diverse companies. Lucas, Fleming, and Bhosale (2018) summarized that.

An increasing number of universities, both domestic and globally, are promoting WIL as a crucial part of their strategic plans, as this approach is one that can satisfy government and stakeholders (industry, parents, and students) need for work-ready, future-ready graduates. Consequently, the diversity of WIL contexts is likely to continue to grow and expand. In addition, as the nature of work and the workplace continues to evolve the requirement to explore new and emerging approaches to WIL will also increase. (p. 221) 
The TESOL team meetings allowed different instructors to share their class-specific selections and the documentation they provided for their teaching and student learning outcomes. The assembled materials and student products required a syllabus for each class and explanations for the materials and student products the instructors selected. The directors provided feedback and guidance to the instructors, so the assembled class evidence was manageable for review while maintaining the emphasis and highlights each instructor found essential for student development.

\section{Ongoing Assessment}

In large part, the TESOL program accreditation success was attributed to the ongoing assessments. The success was built on the continuous evaluations of student outcomes and professional competencies, and the professional development of faculty and staff. Curriculum and courses were reviewed yearly to update materials and content.

Courses were not the only focus, technological support was an essential part as the entire set of student products, teaching materials, and syllabi had to be uploaded and prepared for the accreditation team to review online as well as in hand evidence. Updates were reviewed together, and the technology expert uploaded all the comprehensive course evidence and student learning outcomes documentation.

Students were also invited to appropriate meetings and they shared their perspectives related to the program and courses. Improvements were not delayed, and appropriate suggestions were implemented as soon as possible. It was documented that improvements suggested by students and faculty were addressed because the meetings were about the program's ongoing improvement. The consistent, authentic evidence of dedication to excellence was a positive impact on accreditation.

The essence of the accreditation meetings and the ongoing assessments met the WSCUC standard tasks in the most beneficial manner possible. The assembled syllabi, comprehensive course packets, and directors' supplemental documents, and other issues were addressed. The WSCUC standards required documentation regarding the students' professional exposure and professional stakeholders' input regarding program development. Each semester meetings were scheduled with TESOL professionals, outside the university, where they shared updated information related to the field. Their suggestions regarding the Master's program were recorded, addressed, and future reports noted the outcomes of their suggestions. Such meetings were beneficial to the professors and students alike and provided a venue for including external expertise.

\section{Alternative Meeting Strategies}

The Delphi Technique has functional similarities to the meetings the TESOL team practiced; however, there were significant differences (Ilyas, 2019). The TESOL team met on a continuous schedule and was led by a designated director, professor, or staff member associated with the meeting agenda. It was a comfortable collaborative group well known to one another.

Ilyas (2019) explained that the Delphi Technique's more structured format could benefit a university with a larger faculty or a different communication style. Over several years, the TESOL team and professors worked together regularly and were able to comfortably share different opinions or perspectives. Their mutual respect and shared experiences provided an atmosphere of comfortable task completion and candid suggestions that might not be possible due to different group circumstances 
(Ilays, 2019). The Delphi Technique has worked well for other universities and is certainly worth consideration. Ilyas (2019) suggested.

...using the Delphi technique to evaluate the current scenario and ensure predictability judgments for a successful implementation of...best practices. As a group communication technique, the Delphi technique ideally suited this study making use of a group of individuals (e.g Faculty, Assessors) engaging themselves in resolving complex issues through a consensus. The Delphi technique is also indispensably relevant where no historical data exist, as many programs in Saudi universities are still not accredited.

Finally, the Delphi Technique is also a method that helps identify risks, reduce bias in the data and estimate the outcome of events, truly representing predictability and versatility. (p. 148)

An additional and effective program assessment handbook for ongoing meetings was offered by the Western Washington University (WWU) (2006): 1) Systematic. It is an orderly and open method of acquiring assessment information over time; 2) Built around the department mission statement. It is an integral part of the department or program; 3) Ongoing and cumulative. Over time, assessment efforts build a body of evidence to improve programs; 4) Multi-faceted. Assessment information is collected on multiple dimensions, using multiple methods and sources; 5)Pragmatic. Assessment is used to improve the campus environment, not simply collected and filed away 6) Facultydesigned and implemented, not imposed from the top down.... (p.35)

The WWU (2006) handbook provided a summarized agenda list for the ongoing tasks for program assessment and meeting accreditation standards: 1) Agree on your mission; 2) Create goals for student outcomes and processes; 3) Identify related activities for each goal; 4) Brainstorm appropriate measures; 5) Evaluate and select measures; 6) Identify appropriate assessment methods; 7) Develop a plan for collecting data Prioritize goals; 8) Set timeline, milestones; 9) Implement assessment plan; 10) Use data to improve processes; 11) Communicate results. (p. 3-4).

Meeting agendas, plans, timelines, and techniques can be adapted to create a positive collaborative environment for successfully addressing the numerous tasks required to address all an accreditation commission's expectations and requirements. Each accreditation commission or agency will have specific standards that the investigation teams expect to be met to some degree. Wording may vary, but the categories generally are considered as not met, met with contingencies, met, and exceeded standard requirements (WSCUC, 2013; NWCCU 2020). The information shared encourages academic administrations to support the extensive time, commitment, and efforts required to successfully address all accreditation standards.

The TESOL meetings and ongoing assessments were the foundation of accreditation success. A step that helped crystalize the program and individual student learning outcomes was the development of a simple but effective program matrix.

\section{Program Matrix Technique}

In the International Academic Forum (IAFOR) Journal of Education, Montoneri (2014) thoroughly discussed research related to teaching and learning assessment and agreed with others that statistical analysis increasingly uses matrices to analyze the effectiveness of university programs (Colbert, Levary, \& Shaner, 2000). Montoneri noted that various applications of 
management matrices are being implemented. Montoneri (2014) explained that "A number of studies have designed two-dimensional, categorical conceptions of performance quality collectively called management matrices; these matrices have been found to be useful in understanding and improving a variety of job performances" (p. 130). The author applied the use of matrices in an educational context.

The TESOL team collaboratively designed a matrix that identified the types of assignments per course within the program. The visualization allowed the directors and relevant professors to discover the overuse of some assignments. They discussed options for better balance regarding the workload per class. The first matrix provided a way to immediately assess the course assignments situation. For clarification, the presentations and PowerPoint assignments allowed students to share their development of lesson plans, projects, or case study analysis; the presentations were not separate assignments but rather considered opportunities to showcase student efforts.

Tabel 1. Course Outcomes Matrix Technique

\begin{tabular}{|c|c|c|c|c|c|c|c|c|c|c|}
\hline Courses & Student Out & mes & & & & & & & & \\
\hline & $\begin{array}{l}\text { Presentation } \\
\text { PowerPoint } \\
\text { (Related) }\end{array}$ & Project & $\begin{array}{l}\text { Lesson } \\
\text { Plan(s) }\end{array}$ & Paper & $\begin{array}{l}\text { Self- } \\
\text { Reflection } \\
\text { Paper }\end{array}$ & $\begin{array}{l}\text { Journal } \\
\text { Article } \\
\text { Review }\end{array}$ & $\begin{array}{l}\text { Case } \\
\text { Study }\end{array}$ & $\begin{array}{l}\text { Ethno- } \\
\text { graphic } \\
\text { Study }\end{array}$ & $\begin{array}{l}\text { Literature } \\
\text { Review }\end{array}$ & Research \\
\hline Methods & $\mathrm{X}$ & $\mathrm{X}$ & & $\mathrm{X}$ & & & & & $\mathrm{X}$ & \\
\hline $\begin{array}{l}\text { Teaching Listening } \\
\text { \& Speaking } \\
\text { Reading }\end{array}$ & $\begin{array}{l}X \\
X\end{array}$ & $\mathrm{X}$ & $\mathrm{X}$ & & & $\mathrm{X}$ & $\mathrm{X}$ & & & \\
\hline Writing & $\mathrm{X}$ & $\mathrm{X}$ & $\mathrm{X}$ & & & & & & & \\
\hline Linguistics & $\mathrm{X}$ & & & & $\mathrm{X}$ & $\mathrm{X}$ & & $\mathrm{X}$ & $\mathrm{X}$ & \\
\hline $\begin{array}{l}\text { Grammar/ } \\
\text { Vocabulary } \\
\text { Culture }\end{array}$ & $\begin{array}{l}X \\
X\end{array}$ & $\begin{array}{l}X \\
X\end{array}$ & $\begin{array}{l}X \\
X\end{array}$ & $\mathrm{X}$ & $\mathrm{X}$ & & $\mathrm{X}$ & $\mathrm{X}$ & $\mathrm{X}$ & \\
\hline $\begin{array}{l}\text { Research Methods } \\
\text { \& Statistics } \\
\text { Practicum/ } \\
\text { Dissertation Plan }\end{array}$ & $\mathrm{X}$ & $\mathrm{X}$ & & & $\mathrm{X}$ & $\begin{array}{l}X \\
X\end{array}$ & & & $\begin{array}{l}X \\
X\end{array}$ & $\begin{array}{l}X \\
X\end{array}$ \\
\hline $\begin{array}{l}\text { Practicum/ } \\
\text { Dissertation } \\
\text { Progress } \\
\text { Dissertation }\end{array}$ & & & & & $\mathrm{X}$ & & & & $\mathrm{X}$ & $\begin{array}{l}X \\
X\end{array}$ \\
\hline
\end{tabular}

\begin{tabular}{|c|c|c|c|c|c|c|c|c|c|c|c|}
\hline \multirow[t]{2}{*}{ Courses } & & \multicolumn{10}{|c|}{ Student Outcomes } \\
\hline & & $\begin{array}{l}\text { Presentation } \\
\text { PowerPoint } \\
\text { (Related) }\end{array}$ & Project & $\begin{array}{l}\text { Lesson } \\
\text { Plan(s } \\
\text { ) }\end{array}$ & Paper & $\begin{array}{l}\text { Self- } \\
\text { Reflection } \\
\text { Paper }\end{array}$ & $\begin{array}{l}\text { Journal } \\
\text { Article } \\
\text { Review }\end{array}$ & $\begin{array}{l}\text { Case } \\
\text { Study }\end{array}$ & $\begin{array}{l}\text { Ethno- } \\
\text { graphic } \\
\text { Study }\end{array}$ & $\begin{array}{l}\text { Literature } \\
\text { Review }\end{array}$ & Research \\
\hline Methods & & $\mathrm{X}$ & $\mathrm{X}$ & & $\mathrm{X}$ & & & & & $\mathrm{X}$ & \\
\hline $\begin{array}{l}\text { Teaching } \\
\text { Listening } \\
\text { Speaking }\end{array}$ & $\&$ & $\mathrm{X}$ & $\mathrm{X}$ & & & & & $\mathrm{X}$ & & & \\
\hline Reading & & & & $\mathrm{X}$ & & & $\mathrm{X}$ & & & & \\
\hline Writing & & $\mathrm{X}$ & & $\mathrm{X}$ & & & & & & & \\
\hline Linguistics & & $\mathrm{X}$ & & & & $\mathrm{X}$ & $\mathrm{X}$ & & $\mathrm{X}$ & & \\
\hline $\begin{array}{l}\text { Grammar/ } \\
\text { Vocabulary }\end{array}$ & & $\mathrm{X}$ & $\mathrm{X}$ & $\mathrm{X}$ & $\mathrm{X}$ & & & & & & \\
\hline Culture & & $\mathrm{X}$ & & $\mathrm{X}$ & & $\mathrm{X}$ & & $\mathrm{X}$ & $\mathrm{X}$ & & \\
\hline $\begin{array}{l}\text { Research M } \\
\& \text { Statistics }\end{array}$ & & & & & & & & & & $X$ & $X$ \\
\hline
\end{tabular}




\begin{tabular}{lc}
\hline Practicum/ & $\mathrm{X}$ \\
Dissertation Plan & $\mathrm{X}$ \\
Practicum/ & $\mathrm{X}$ \\
Dissertation & $\mathrm{X}$ \\
Progress & $\mathrm{X}$ \\
\hline Dissertation & \\
\hline
\end{tabular}

Designed by Drs. Butler-Pascoe, Baker, and Kelch.

The second matrix reveals the results of the TESOL team discussions and interactive dialogues that had some professors deleting an assignment or adding a different one. The entire focus was on the students' professional development related to TESOL competencies. The positive result of teaching how to develop a literature review in the Methods course allowed the professor to provide the students with a deeper understanding of a literature review formatting. The students developed literature review skills that were well documented. Students were better prepared for their research and practicum or dissertation assignments.

Students appreciated the improved balance of assignment workloads. Professors were able to see that they could better teach fewer class expectations and were more supportive of designing well-prepared rubrics or guidelines for each assignment. The greater clarification of assignment expectations resulted in more proficient and advanced student products. All courses were intentional in the specific content and student development.

Prior to creating the matrix, professors felt responsible for teaching everything and did not fully appreciate that different courses addressed the same content. The TESOL meetings allowed instructors the opportunity to determine the optimal content and assignments for each course. Faculty, students, and the program benefitted from the revisions.

\section{Four Assessment Steps}

The Missouri State University (MSU) Assessment Plan Instructional Webinar (NA) provided guidance for assessing a program's matrix using four steps: 1) Clearly define and identify the learning outcomes; 2) Select appropriate assessment measures and assess the learning outcomes; 3) Analyze the results of the outcomes assessed; 4) Adjust or improve programs following the results of the learning outcomes assessed.

The TESOL team had previously applied the conceptualization of the MSU webinar four steps for analysis. Student outcomes were identified and the rubrics, guidelines, and explanations for each assignment were provided in the course syllabus or at the time the assignment was

introduced. Related to Step 1, if students did not have a clear understanding of the assignment expectations or requirements, they had ample opportunities to clarify their questions with the instructor. Professors were available to students during office hours, after class sessions, via email, and during phone calls.

Within the TESOL Master's program, each assignment was well defined with guidelines and rubrics that clarified the grading criteria for the assignment. Step 2 was critical to student confidence when meeting course expectations. The important understanding and student development were addressed in the rubrics and materials provided. Assessment options included academic papers, presentations with PowerPoints, journal article reviews, case studies, self-assessment papers, lesson plans, and demonstration of skills developed unique to the assignment.

Step 3 was addressed from the beginning of instructor selection when teaching 
responsibilities were thoroughly explained. Students received grades that included a professor's comments noting what was well prepared and at times where the assignment did not meet the guidelines or rubric expectations. If there were legitimate reasons for a grade analysis with the student, they were invited to discuss the questions with the course instructor. The attention to rubric design and guideline instructions alleviated most questions or possible misunderstandings related to the assignments. The encouragement from instructors and the available support led to student success.

The Webinar's Step 4 was critical to the ongoing rigor and content value of each course. The collective directors and course instructor addressed immediate concerns that arose (noted by the instructor or by students). The appropriate adjustments were made to address issues as they arose, or the improvements were applied for the next teaching cycle. The ongoing assessment and corrections kept the courses vital and allowed students to know that their concerns were taken seriously. The issues are thoroughly discussed, and various viewpoints were shared as only appropriate amendments were considered for the enhancement of student development.

\section{Assessment and Accreditation}

Garfolo and L'Huillier (2015) offered articulate insights into the issues of assessing student development and learning outcomes. Their contribution to understanding assessments related to accreditation and ongoing program enhancement was valuable. Garfolo and L'Huillier (2015) stressed that:

Student learning improvement is at the heart of assessment. When faculty are directly involved in the assessment process, they can take ownership of the process, and in doing so gain many intrinsic and extrinsic benefits from their participation including a sense of personal and professional satisfaction at successful outcomes. The three questions that must be asked at the start of any assessment process are: 1) What should students be learning?; 2) What are students actually learning?; 3) What should you, the instructor, be doing to facilitate student learning?.

Ultimately, assessment (for accreditation) is conducted to bring about improvement at all levels from course-to-program-to-theinstitution. This is accomplished by establishing clear and measurable outcomes of student learning and by documenting and demonstrating that student learning has occurred. Through the process of assessment, evidence is generated to show that students have multiple opportunities to reach the specified outcomes that have been established. Finally, assessment reveals if students are learning what they have been taught or, if what they are being taught is what they need to learn. (p. 152-153)

\section{Conclusion}

Global perspectives that provided relevant information was included throughout the article as a means of recognizing the globalization of accreditation standards. The broad views confirm that colleges, universities, and governments determine curriculum governance and that standards are often the same or similar. Quality assurance is a fundamental goal within the process of successful self-studies and eventual accreditation success.

The in-depth considerations related to accreditation purpose, value, and benefits extended into the discussions of collaborative teams devising strategies and tasks that would meet accreditation standards. The foundational concept, related to standards across commissions, was the importance of excellence in teaching and learning. The technique for maintaining 
meetings provided effective planning strategies and assessment task assignments. The program assessment matrix provided a visual for a better selection of courses related to student learning outcomes. This article highlights the importance of quality assurance measures. Examples for planning and steps for achieving accreditation success were woven throughout the writing.

Accreditation success cannot be fully embraced in a single article. Nonetheless, the provisions for planning and the examples provided clarified numerous strategies and techniques for moving a degree program toward positive assessment reviews. Understanding the merits of assessment, confidence in the planning, collaborative and productive meetings, effective task assignments, and a matrix that substantiates evidence of student competencies are the proficiencies that will, to a large degree, lead a degree program to accreditation success.

\section{References}

Bahr, M. (2018). Valuing the accreditation process. NADE Digest [Winter], 16.

Casazza, M. (2018). Accreditation: A valueadded proposition. NADE Digest [Winter], 3-7. Choiriyah, S., Kumaidi, \& Kartowagiran, D. (2018). Developing Delta Internal Quality Assurance to evaluate the quality of Indonesian Islamic universities. Journal of Social Studies Education Research, 9(3), 177-197.

Colbert, A., Levary, R., \& Shaner, M. (2000). Determining the relative efficiency of MBA programs using DEA. European Journal of Operational Research, 125(3), 656-660.

Corpus, M. (n.d.). Agency of Chartered Colleges and Universities in the Philippines. (n.d.). The Stages of Accreditation 1-4. Retrieved January 27, 2021 from AACCUPhttp://www.aaccupqa.org.ph/ind ex.php/aaccup-accreditation.
Ferguson, J. \& Ludman, N. (2018). An overview of NADE accreditation. NADE Digest [Winter], 9-10.

Garfolo, B. T. \& L'Huillier, B. (2015). Demystifying assessment: The road to accreditation. Journal of College Teaching \& Learning [Third Quarter], 12(4), 151169.

Gibbons, H. \& White, H. (2019). A comparative study of LIS accreditation frameworks in Australia, New Zealand, United States, and Canada. Journal of Education for Library and Information Science, 60(4) 241-264.

Ilyas, M. (2019). Determining critical success factors for quality and accreditation through Delphi Technique. International Journal of Higher Education, 8(3), 148158.

Higher Learning Commission. (2020). New criteria for accreditation. 1-8. Retrieved January 27, 2021, from https://www.hlcommission.org/

Ilyas, M. (2019). Determining critical success factors for quality and accreditation through Delphi Technique. International Journal of Higher Education, 8(3), 148158.

Lucas, P., Fleming, J., \& Bhosale, J. (2018). The utility of case study as a methodology for work integrated learning research. International Journal of Work-Integrated Learning [Special Issue], 19(3), 215-222.

Mc Allister, L. \& Nagarajan, S.V. (2015). Accreditation requirements in allied health education: strengths, weaknesses, and missed opportunities. Journal of Teaching and Learning for Graduate Employability, 6(1), 2-24.

Montoneri, B. (2014). Teaching improvement model designed with DEA Method and management matrix. The IAFOR Journal of Education [Winter], 2(1) 1-31. Retrieved February 4, 2021, from Missouri State University, Assessment Plan 
Documents MSU Public Affairs Mission Assessment Plan Instructional Webinar. https://www.missouristate.edu/assessment/ the-assessment-process.htm

NADE Accreditation Commission. (2018). NADE accreditation: The right decision for the current time. National Association for Developmental Education. Retrieved January 27, 2021 from https://thenade.org/Mission-Vision-andGoals.

Northwest Commission on Colleges and Universities. (2020). Accreditation standards and policies: NWCCU 2020 Standards. Retrieved January 27, 2021 from https://nwccu.org/accreditation /standards-policies/standards/

Oraison, H., Konjarski, L., \& Howe, S. (2019). Does university prepare students for employment? Alignment between graduate attributes, accreditation requirements, and industry employability criteria. Journal of Teaching and Learning for Graduate Employability, 10(1), 173-194.

Prince, D. (2012). American accreditation: Why do it? Higher Learning Research Communications, 2(3), 45-51.
Rosyidah, R., Matin, \& Rosyidi, U. (2020). Internationalization in higher education: University's effective promotion strategies in building international trust. European Journal of Educational Research, 9(1), 351-361. Retrieved January 27, 2021 from https://doi.org/10.12973/eu-jer.9.1.351

Western Washington University. (2006). Tools and techniques for program improvement: A handbook for program review and assessment of student learning. 1-128. Frye, R., McKinney, G.R., \& Trimble, J.E. Available through the Office of Institutional Assessment, Research, and Testing (OIART), Retrieved January 27, 2021, from OIART website at www.wwu.edu/depts/pdfassess/

Western Senior College and University Commission. (2013). Accreditation resources handbook. Retrieved January 27, 2021 from https://www.wscuc.org /resources/handbookaccreditation2013/part-ii-core-commitments-andstandards-accreditation/wasc standardsaccreditation-2013. 